\title{
Why Western World Caught Unaware by Corona Virus Catastrophy?
}

\author{
Fatih Yalçın*
}

Director, Department of Cardiology, HATAY Mustafa Kemal University Hospital, Antioch, HATAY, TURKEY. Fulbright Visiting Professor, Johns Hopkins University, USA

*Corresponding author: Fatih Yalçın, Director, Department of Cardiology, HATAY Mustafa Kemal University Hospital, Antioch, HATAY, TURKEY. Fulbright Visiting Professor, Johns Hopkins University, USA

\begin{tabular}{|c|c|}
\hline ARTICLE INFO & ABSTRACT \\
\hline Received: November 02, 2020 & Citation: Fatih Yalçın. Why Western World Caught Unaware by Corona Virus Catastrophy?. \\
\hline Published: November 09, 2020 & Biomed J Sci \& Tech Res 31(5)-2020. BJSTR. MS.ID.005150. \\
\hline
\end{tabular}

\section{Opinion}

Western world has been defeated by corona virus unexpectedly. The underlying mechanism of potential chaotic circumstances should be evaluated carefully to prevent recurrent events. It is a debate whether western world has given enough importance to microbial incidents. As a medical doctor, when I was an imaging fellow at the Cleveland Clinic in 1998, I had a positive PPD which represents that my body previously produced a cellular immunity for tuberculosis bacteria because I had BCG vaccine. Surprisingly, this finding was not interpreted as a positive immunity at the clinic. They rather accepted my finding as a previous contact with mycobacterium tuberculosis. After catastrophic incident of corona virus, we have just learned that PPD (+) reaction which is related to interferon gamma as the recently documented protective indicator for mortality due to covid 19 is protective for severity of

\section{ISSN: 2574-1241}

DOI: 10.26717 /BJSTR.2020.31.005150

Fatih Yalçın. Biomed J Sci \& Tech Res

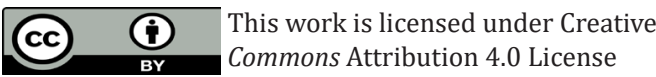

Submission Link: https://biomedres.us/submit-manuscript.php corona virus infection. In global perspective, it has been realized that it is not enough nation-based eradication of microbial agents and this kind of chaotic incidents could become a global problem.

Therefore, even though this agent came from China, a lot of people from Western World visit China and similar health problems could also be the case. As an academician, I would emphasize that Western World should learn 2 lessons from this incident.

a) All nations should take responsibility for human being wellness world-widely.

b) Justice of Nature could balance some antidemocratic behavior like unfair competition against Huawei success which has also been mentioned by Boris Johnson by declaring that England will work with Huawei.

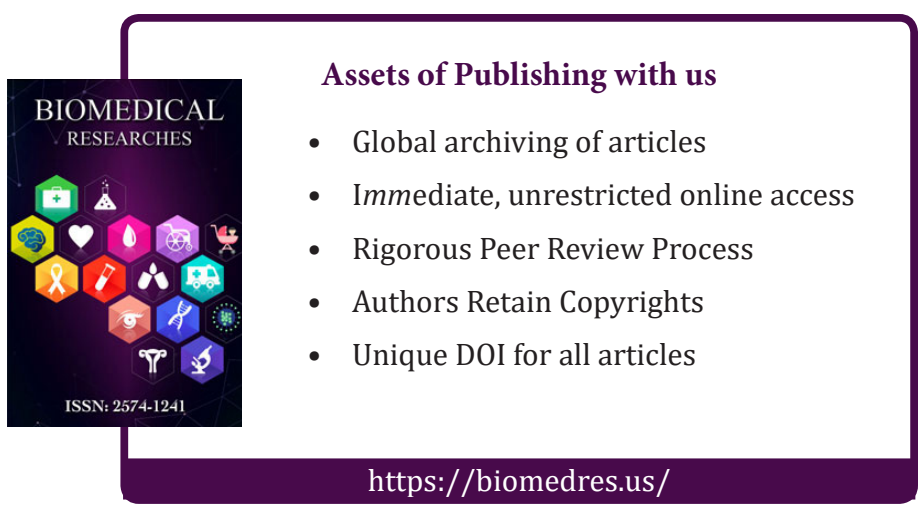

